\title{
A review on maximum length of the greater weever Trachinus draco Linnaeus 1758 (Perciformes: Trachinidae) with a new maximum length from Oran Bay (Western Algeria)
}

\author{
Lotfi BENSAHLA-TALET ${ }^{1,2}{ }^{(0}$, Hichem ADDA NEGGAZ ${ }^{2}(\mathbb{0}$
}

Cite this article as:

Bensahla-Talet, L., Adda Neggaz, H. (2021). A review on maximum length of the greater weever Trachinus draco Linnaeus 1758 (Perciformes: Tachinidae) with a new maximum length from Oran Bay (Western Algeria). Aquatic Research, 4(1), 55-64. https://doi.org/10.3153/AR21005

${ }^{1}$ University Oran1 Ahmed Benbella, Faculty of Natural Science and Life, Department of Biology, Laboratory of Aquaculture and Bioremediation (AQUABIOR), 31000, Oran Algeria.

${ }^{2}$ University Oran1 Ahmed Benbella, Faculty of Natural Science and Life, Department of Biology, Laboratory Environmental Monitoring Network (LRSE), 31000, Oran Algeria.

\section{ABSTRACT}

On the $15^{\text {th }}$ April 2017, one female specimen of the greater weever, Trachinus draco measuring $44.69 \mathrm{~cm}$ in total length and weighting $885 \mathrm{~g}$ was captured by trammel net in Oran Bay (Cape Rousseau) at $120 \mathrm{~m}$ depth. Up to date, this length is a new record of maximum length reached for this trachinidae for Algerian waters and the second maximum length recorded in Mediterranean basin according to Fischer et al., 1987 observation noted at $45 \mathrm{~cm}$.

Keywords: The greater weever, Trachinus draco, Maximum size, Oran Bay, Mediterranean Sea

ORCID IDs of the author(s):

L.B.T. 0000-0002-8360-2079

H.A.N. 0000-0002-5672-5129

Submitted: 28.05 .2020

Revision requested: 07.07 .2020

Last revision received: 13.07 .2020

Accepted: 13.07.2020

Published online: 23.11.2020

Correspondence:

Lotfi BENSAHLA-TALET

E-mail: btlotfi1977@gmail.com

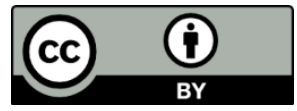

(C) 2021 The Author(s) 


\section{Introduction}

The greater weever is a trachinidae found in Eastern Atlantic; Norway to Morocco, Madeira and Canary Islands, including the Mediterranean and the Black Sea (Fischer et al., 1987; FishBase: Froese and Pauly, 2020). Trachinus draco Linnaeus 1758 inhabits sandy, muddy or gravelly bottoms, from a few meters to about $150 \mathrm{~m}$. Rest on the bottom, often buried with eyes and tip of first dorsal fin exposed (Frimodt, 1995). The first dorsal fin rays, as well as the spine on the pre-operculum contains venomous spines protecting the species from predators. During night, the greater weever leaves the burrow to feed on small invertebrates and fishes (Carpenter et al., 2015). At night, it also swims around freely, even pelagically (Muus and Nielsen 1999). T. draco is oviparous, eggs and larval stages are pelagic (Tortonese, 1986). There are dark markings along the scales; the anterior dorsal fin is black and contains venomous spines. Its length is very common between 10 and $30 \mathrm{~cm}$ with a maximum of $45 \mathrm{~cm}$ in the Mediterranean and common between 15 to $20 \mathrm{~cm}$ with a maximum of $36 \mathrm{~cm}$ in the Black Sea (Fischer et al., 1987).

Available bibliography for $T$. draco is diversified dealing with reproduction (Bagge, 2004; Ak and Genç, 2013), Parasites (Azizi et al., 2016; Kayiş and Er, 2016), lipid content (Loukas et al., 2010), feeding habits (Santic et al., 2016), population structure and dynamics (Quigley, 1994; Portillo Strempel et al., 2008; Buz and Basusta, 2015; Carpenter et al., 2015; Custovic et al., 2014) but most of them focused on envenomation and toxin properties (Muir evans 1907; Skeie, 1962; Chahl and Kirk, 1975; Perriere and Michel, 1986; Halstead and Vinci, 1987; Chhatwal and Dreyer, 1992; Bouree and Lançon, 2002; Church and Hodgson, 2002; Acciaro et al., 2003; Verdiglione et al., 2003; Berger and Caumes, 2004; Russell and Emery, 2006; Lopacinski et al., 2009; Benlier et al., 2010; Portillo Strempel and Ceballos, 2012) and mainly on weight length relationship (Dorel 1986; Coull et al., 1989; Gonçalves et al., 1997; Merella et al., 1997; Moutopoulos and Stergiou, 2002; Mendes et al., 2004; Mendes et al., 2006; Ozaydin et al., 2007; Karakulak et al., 2006; lkyaz et al., 2008; Mata et al., 2008; Ak et al., 2009; Giacalone et al., 2010; Benmessaoud et al., 2015; Öztekin et al., 2016; Özdemir et al., 2017; Hamed et al., 2016).

In fisheries science maximum length and maximum age are important theoretical parameters found as entry data in majority of the models used in stock assessments (Allen, 1971; Pauly, 1980; Welcomme, 1999; Froese and Binohlan, 2000).
In this context, updating the maximum size of a species harvested for commercial or recreational purposes is gaining more importance (Borges, 2001; Dulčić and Soldo, 2005; Akyol and Şen, 2008). The maximum observed length is a useful tool for a rapid evaluation of growth rates in the absence of basic data (Legendre and Albaret, 1991, Froese and Binohlan, 2000). To date, for Algerian waters no such studies were leaded on this trachinidae.

\section{Material and Methods}

On the $15^{\text {th }}$ April 2017, one female specimen of the greater weever, Trachinus draco measuring $44.69 \mathrm{~cm}$ in total length and weighting $885 \mathrm{~g}$ was captured by captured by trammel net operating in Oran Bay (Cape Rousseau: $35^{\circ} 48^{\prime} 45.0^{\prime \prime} \mathrm{N}$ $0^{\circ} 36^{\prime} 46.8^{\prime \prime} \mathrm{W}$ ) on sandy/rocky bottom at $120 \mathrm{~m}$ depth (Fig. $1)$.

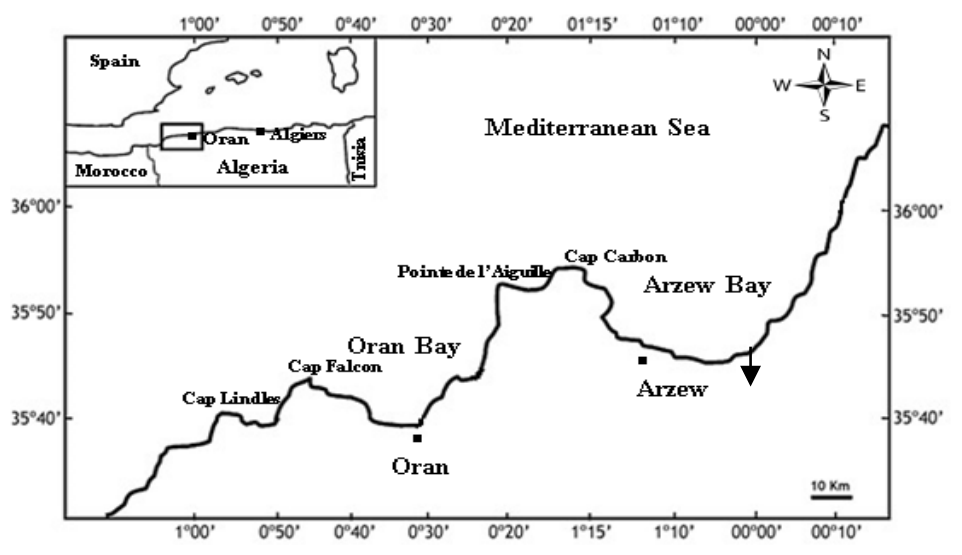

Figure 1. Sampling location of greater weever (Trachinus draco) specimen.

The specimen was measured with an electronic caliper to 0.1 $\mathrm{mm}$ precision and weighted to the nearest $0.1 \mathrm{~g}$ then photographed. Eighteen morphometric characteristics were measured (Figure 2): Total length (TL), Fork length (FL), Standard length (SL), Pectoral fin length (LP), Ventral fin length (LV), 1 st dorsal fin length (LD1), 2nd dorsal fin length (LD2), Cephalic length (LC), Maxillary length (LM), Post-orbital distance (POD1), Eye diameter (O), Post-orbital distance (POD2), Pre-ventral fin distance (PVD1), Post-ventral fin distance (PVD2), Anal fin length (LA), Post-anal fin distance (PAD), Caudal peduncle minimal depth (T), Maximum body height (TPC), Total weight (TW). Description, measurements and percentage of each body part are reported to total length are given in (Table 1). 


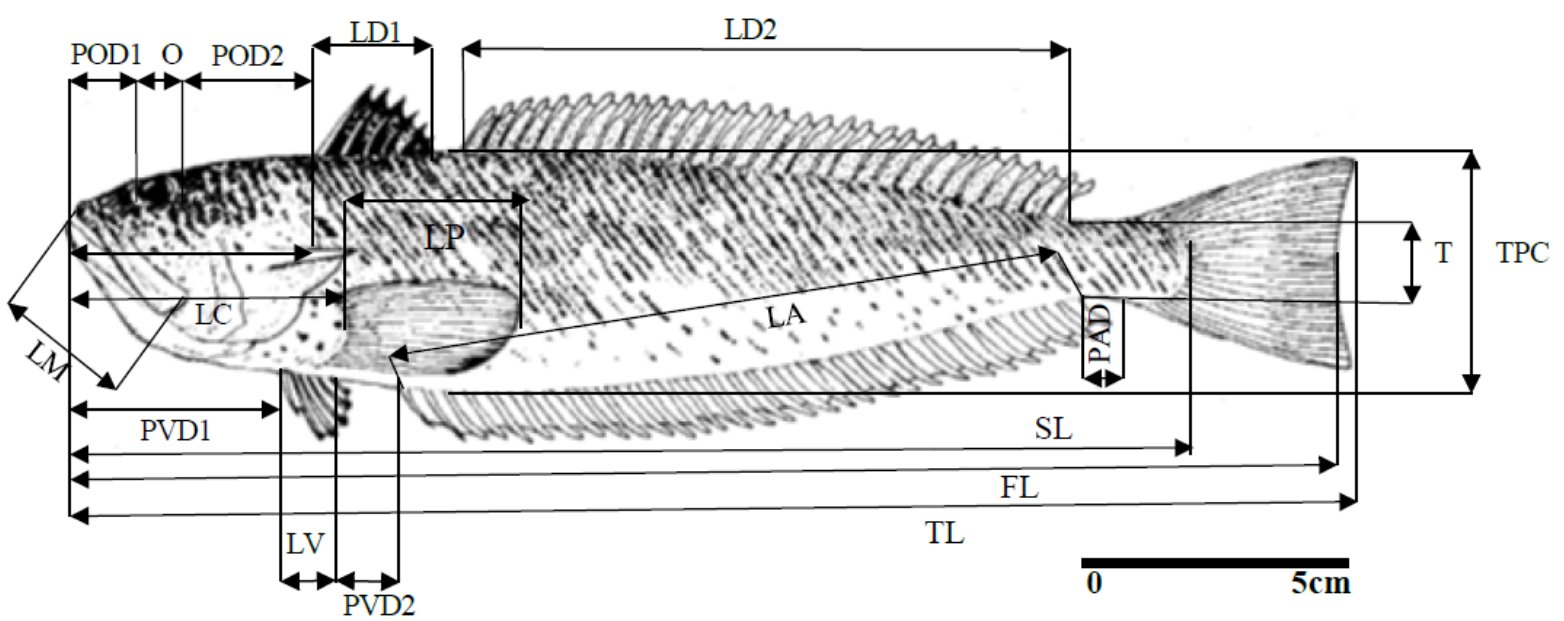

Total length (TL), Fork length (FL), Standard length (SL), Pectoral fin length (LP), Ventral fin length (LV), Cephalic length (LC), Maxillary length (LM), Pre-orbital distance (POD1), 1st Dorsal fin length (LD1), 2nd Dorsal fin length (LD2), Eye diameter (O), Post-orbital distance (POD2), Anal fin length (LA), Caudal peduncle minimal depth (T), Maximum body height (TPC), Pre-ventral fin distance (PVD1), Post-anal fin distance (PAD), Post ventral fin distance (PVD2).

Figure 2. Morphometric measurements of the greater weever Trachinus draco adapted from Fischer et al. (1987).

\section{Results and Discussion}

On the $15^{\text {th }}$ April 2017, one female specimen of the greater weever, Trachinus draco measuring $44.69 \mathrm{~cm}$ in total length and weighting $885 \mathrm{~g}$ was captured by trawler operating in Oran Bay at $120 \mathrm{~m}$ depth. Species identification sheets (Fischer et al., 1987; Djabali et al., 1993) were used to identify the specimen of $T$. draco (Fig.3) where the body appear elongated and compressed. Small eyes located near the dorsal profile of the head; width of the interorbital space roughly equal to half the diameter of the eye; large oblique mouth, the maxillary extending beyond the posterior edge of the eye when the mouth is closed with villiform teeth.

According to Fischer et al., (1987) T. draco has a strong venomous spine on the operculum, 2 spines on the anterodorsal edge of the orbit and another above the upper lip, in front of the eye. Two dorsal fins, the first short counting 5 to 7 spines, the second, long counting 29 to 32 soft rays; anal with 2 spines and 29 to 32 soft rays. Generally, the greater weever is

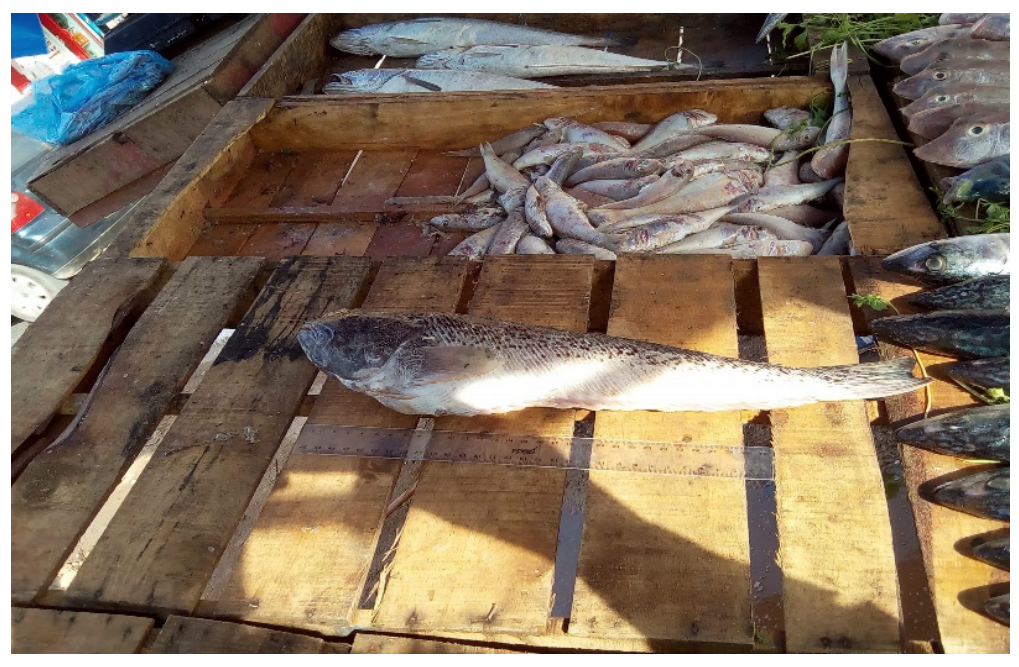

Figure 3.Trachinus draco ( $44.69 \mathrm{~cm}$ TL 9 ) caught in Oran Bay, (Photographed by: ADDA NEGGAZ Hichem). greenish brown back with dark spots on the head, yellowishwhite flanks according to the oblique rows of scales, of brown, blue, yellow lines; second dorsal fin yellowish, anal mauve. 
Measurements, meristic characteristics, weight and percentage of each body part of the greater weever caught in Oran Bay reported to total length are given in (Table 1).

Table 1. Morphometric measurements as percentage of total length (\% TL) of Trachinus draco caught in Oran Bay (W. Mediterranean Sea).

\begin{tabular}{|c|c|c|}
\hline Morphometric characteristics & Measurement & Proportion \\
\hline & (cm) & (\%) \\
\hline Total length (TL) & 44.69 & 100.00 \\
\hline Fork length (FL) & 43.44 & 97.20 \\
\hline Standard length (SL) & 39.30 & 87.94 \\
\hline Pectoral fin length (LP) & 5.76 & 12.90 \\
\hline Ventral fin length (LV) & 3.28 & 7.360 \\
\hline $1^{\text {st }}$ dorsal fin length (LD1) & 2.74 & 6.140 \\
\hline $2^{\text {nd }}$ dorsal fin length (LD2) & 19.76 & 44.22 \\
\hline Cephalic length (LC) & 7.67 & 17.16 \\
\hline Maxillary length (LM) & 1.41 & 3.160 \\
\hline Post-orbital distance (POD1) & 2.96 & 6.620 \\
\hline Eye diameter $(\mathrm{O})$ & 0.77 & 1.720 \\
\hline Post-orbital distance (POD2) & 5.68 & 12.72 \\
\hline Pre-ventral fin distance (PVD1) & 6.15 & 13.78 \\
\hline Post-ventral fin distance (PVD2) & 2.70 & 6.060 \\
\hline Anal fin length (LA) & 25.70 & 57.51 \\
\hline Post-anal fin distance (PAD) & 2.66 & 5.950 \\
\hline Maximum body height (TPC) & 2.57 & 5.750 \\
\hline Caudal peduncle minimal depth $(\mathrm{T})$ & 8.40 & 18.80 \\
\hline Total weight (TW) & 0.88 & - \\
\hline
\end{tabular}

\begin{tabular}{l|c}
\hline \multicolumn{2}{c}{ Meristic characteristics } \\
\hline Operculum spines & $2^{*}$ \\
\hline Short eye spines & 2 \\
\hline $1^{\text {st }}$ dorsal fin spines & $7\left(2^{*}+5\right)$ \\
\hline $2^{\text {nd }}$ dorsal fin & 32 \\
\hline Pelvic fin & 6 \\
\hline Pectoral fins & 15 \\
\hline Anal fin & 31 \\
\hline Caudal fin & 16 \\
\hline
\end{tabular}

*: venomous

According to Portillo Strempel et al., 2008 T. draco showed a seasonal migratory behavior, with a preference for shallower waters, up to $75 \mathrm{~m}$ depth during autumn and for deeper waters up to $160 \mathrm{~m}$ depth, during spring in the northern Alboran Sea (SW Mediterranean) which is the case of our specimen captured in April 2017.
The maximum length ever recorded of $T$. draco belongs to IGFA 2001 in the Atlantic Ocean (Canary island, 56cm) and by Otel (2007) in Danube Delta $(53 \mathrm{~cm})$ followed by Fischer et al., $1987(45 \mathrm{~cm})$ in the Mediterranean, all successive records are shown in Table 2.

Greater Weever is caught as bycatch in the majority of fisheries and landings are declared from the following FAO regions: Northeast Atlantic, Mediterranean and Black Sea. The overall trend in landings is one of dramatic fluctuations with a general increase in landings over time (Carpenter et al., 2015). As stated previously little is known on its ecobiology, population trends and most of studies focused on its toxins.

In the Mediterranean Sea, the maximum length of $T$. draco were reported as $45 \mathrm{~cm}$ TL ( $\mathrm{n}=1124) ; 36 \mathrm{~cm}$ from Black Sea (Fischer et al.,1987); If we consider to maximum length recorded during our study so this length represents the maximum length for both Algerian and Western Mediterranean Sea. The aim of this paper is to present a compilation of maximum length for T. draco with a new record for the greater weever caught in Western Mediterranean Sea (Oran Bay).

Wootton 1990; 1999 in Helfman et al. (2009) stated that factors such as temperature, food availability, nutrient availability, light regime, oxygen, salinity, pollutants, current speed, predator density, intraspecific social interactions, and genetics often working in combination, creating large variations in size of fishes of the same and different ages, also populations exposed to high fishing mortality/pressure will respond by reproducing at smaller average sizes and ages. Generally, in the Mediterranean and Black Sea where fishing activity is intensive, the maximum length was relatively low (Table 2) $32 \mathrm{~cm}$ in Tunisian waters, $38 \mathrm{~cm}$ in French waters, 32.9 in Greek waters, $23 \mathrm{~cm}$ in Egyptian waters $\mathrm{cm}$ TL.

Contrarily, in oceanic and northern seawaters individuals doesn't face the same fishing pressure, maximum length appears more important with a maximal length recorded in Canary Islands reaching $56 \mathrm{~cm}$ (IGFA, 2001). In this context, frequenting the eastern part of oranian shoreline an area undergoing a less fishing pressure than the western area (Oran Bay) (Pers.obs) we can explain that our specimen may have reached this maximum length observed. Also, we can add the fact that there is no predator known for T. draco at the top of the trophic chain. 
Table 2. Maximum length records of Trachinus draco given by several authors.

\begin{tabular}{|c|c|c|c|c|c|}
\hline \multicolumn{2}{|l|}{ Location } & \multicolumn{2}{|c|}{ Depth (m) TL (cm) } & \multirow{2}{*}{$\begin{array}{l}\text { TW (g) } \\
235.82^{*}\end{array}$} & \multirow{2}{*}{$\begin{array}{l}\text { References } \\
\text { Karakulak et al., (2006) }\end{array}$} \\
\hline \multirow{11}{*}{ Turkey } & Aegean Sea & $<30$ & 35.2 & & \\
\hline & Saros Bay & $28-370$ & 37.0 & 427.00 & Ismen et al., (2007) \\
\hline & Izmir Bay & - & 34.1 & $288.99 *$ & Ozaydin et al., (2007) \\
\hline & N. Eastern Mediterranean & $5-100$ & 20.0 & 53.18 & Sangun et al., (2007) \\
\hline & Aegean Sea & $30-70$ & 36.6 & $365.42 *$ & Ilkyaz et al., (2008) \\
\hline & Aegean Sea & - & 36.6 & 401.43 & Kınacigil et al., (2008) \\
\hline & Eastern Black Sea & 60 & 35.0 & 549.20 & Ak et al., (2009) \\
\hline & İskenderun Bay & $18-19 m$ & 20.6 & 55.84 & Gökçe et al., (2010) \\
\hline & Eastern Black Sea & 60 & 25.8 & 131.76 & Ak and Genç, (2013) \\
\hline & Iskenderun Bay & - & $\begin{array}{l}28.7 \mathrm{M} \\
32.0 \mathrm{~F}\end{array}$ & $\begin{array}{l}145.21 \\
237.48\end{array}$ & Buz and Basusta, (2015) \\
\hline & Aegean Sea & $0-400$ & 36.4 & 294.00 & Öztekin et al., (2016) \\
\hline \multirow{3}{*}{ Romania } & Black Sea & - & 40 & - & Bănărescu, (1964) \\
\hline & Agigea Eforie Nord Area & $9.3-12.5$ & 16.5 & $18-27$ & Roșca et al., (2010) \\
\hline & Danube Delta & - & 53.0 & - & Otel, (2007) \\
\hline Tunisia & Gulf of Tunis & - & 32.0 & 236.30 & Hamed and Chakroun-Marzouk, (2016) \\
\hline \multirow{2}{*}{ France } & Gulf of Gascogne & - & 38.5 & $317.97 *$ & Dorel, (1986) \\
\hline & Catalan coast & $1-80$ & 38.5 & 375.00 & Crec'hriou et al., (2012) \\
\hline \multirow{5}{*}{ Greece } & Cyclades, Aegean Sea & $4-90$ & 32.5 & & Erzini et al., (1999) \\
\hline & Greece, Aegean Sea & - & 32.0 & $219.03^{*}$ & Moutopoulos and Stergiou, (2002) \\
\hline & Greece, Thermaikos Gulf & - & 30.5 & $189.37 *$ & Karachle and Stergiou, (2008) \\
\hline & Greece North Aegean Sea & $15-800$ & 28.8 & 149.40 & Torres et al., (2012) \\
\hline & Korinthiakos Gulf & $50-300$ & 32.9 & $206.13 *$ & Moutopoulos et al., (2013) \\
\hline \multirow{5}{*}{ Spain } & & $40-80$ & 24.2 & $83.90^{*}$ & Merella et al., (1997) \\
\hline & Balearic Islands & $0.5-1713$ & 26.5 & 125.00 & Morey et al., (2003) \\
\hline & & - & 34.0 & $259.64^{*}$ & Garmon, (2005) \\
\hline & Eastern Atlantic & $<20$ & 29.5 & $167.94 *$ & Mata et al., (2008) \\
\hline & Alboan Sea & $50-164$ & 39.0 & - & Portillo Strempel et al., (2008) \\
\hline \multirow{3}{*}{ Portugal } & Eastern Atlantic Ocean & $13-55$ & 34.0 & $502.06^{*}$ & Gonçalves et al., (1997) \\
\hline & Algarve coast & - & 39.6 & 554.10 & Santos et al., (2002) \\
\hline & Eastern Atlantic & $30-350$ & 39.0 & 460.00 & Mendes et al., (2004) \\
\hline Egypt & Alexandria Bay & $30-200$ & 23.0 & $200.52 *$ & Abdallah et al., (2002) \\
\hline Croatia & Eastern Adriatic & - & 26.8 & 330.00 & Dulčić and Kraljević, (1996) \\
\hline Italy & Sicily & $10-200$ & 29.5 & $169.26^{*}$ & Giacalone et al., (2010) \\
\hline \multirow{3}{*}{ Ireland } & Schull Bay & - & 42.0 & 510.00 & Went, (1973) \\
\hline & Keem Bay (Co Mayo) & - & 35.4 & 311.00 & Quigley et al., (1990) \\
\hline & Ballycotton Bay (Co Mayo) & - & 38.7 & - & Quigley et al., (1994) \\
\hline \multirow{4}{*}{ - } & North East Atlantic & & 35.0 & 344.00 & Coull et al., (1989) \\
\hline & North Sea/North-East Atlantic & - & 36.5 & $352.78 *$ & Wilhelms, (2013) \\
\hline & Western Atlantic, Canary island & - & 56.0 & 1740.00 & IGFA, (2001) \\
\hline & Northern/Central Adriatic & - & 32.8 & - & Custovic et al., (2014) \\
\hline \multirow{2}{*}{ Denmark } & Kattegat & $99-271$ & $32.5 \mathrm{M}$ & 221.40 & Bagge (2004) \\
\hline & & $9.9-2 / .1$ & $37.6 \mathrm{~F}$ & 350.20 & \\
\hline- & $\begin{array}{l}\text { Mediterranean Sea } \\
\text { Black Sea }\end{array}$ & - & $\begin{array}{l}45.0 \\
36.0\end{array}$ & - & Fischer et al., (1987) \\
\hline Algeria & Oran Bay & 120 & 44.69 & 885.00 & Present study \\
\hline
\end{tabular}

\footnotetext{
*Weight calculated from LWR (length weight relationship).
} 


\section{Conclusion}

As conclusion, more efforts and means must be deployed to explore Oran Bay biodiversity deeply, target large specimens and try to study fish population's dynamics and their interaction with different biotopes present in the area (sandy, muddy, rocky, gravelly).

\section{Compliance with Ethical Standard}

Conflict of interests: The authors declare that for this article they have no actual, potential or perceived conflict of interests.

Ethics committee approval: Ethics committee approval is not required for this study.

Funding disclosure: -

Acknowledgments: -

Disclosure: -

\section{References}

Abdallah, M. (2002). Weight-length relationships of fishes caught by trawl off Alexandria, Egypt. Naga ICLARM Q., 25(1), 19-20.

Acciaro, A.L., Caserta, G., Gagliano, M., Busa, R., Landi, A. (2003). La Rigidità Articolare Nella Mano Nelle Lesioni Da Trachinus draco. Rivista di Chirurgia della Mano, 40 (3) 2003.

Ak, O., Kutlu, S., Aydın, İ. (2009). Length-weight relationship for 16 fish species from the Eastern Black Sea, Türkiye. Turkish Journal of Fisheries and Aquatic Sciences, 9(1), 125126.

Ak, O., Genç, Y. (2013). Growth and reproduction of the greater weever (Trachinus draco L., 1758) along the eastern coast of the Black Sea. Journal of Black Sea/Mediterranean Environment, 19(1), 95-110.

Akyol, O., Şen, H. (2008). A new maximum size for Eledone moschata (Cephalopoda: Octopodidae). Marine Biodiversity Records, 1, e 71.

https://doi.org/10.1017/S1755267207007531
Allen, K. R. (1971). Relation between production and biomass. Journal of the Fisheries Research Board of Canada, $28,1573-1581$.

https://doi.org/10.1139/f71-236

Azizi, R., Rangel, L.F., Castro, R., Santos, M.J., Bahri, S. (2016). Morphology, seasonality and phylogeny of Zschokkella trachini n. sp. (Myxozoa, Myxosporea) infecting the gallbladder of greater weever Trachinus draco (L.) from Tunisian waters. Parasitology Research, 115(11), 41294138.

https://doi.org/10.1007/s00436-016-5187-y

Bagge, O. (2004). The biology of the greater weever (Trachinus draco) in the commercial fishery of the Kattegat. ICES Journal of Marine Science, 61(6), 933-943.

https://doi.org/10.1016/j.icesjms.2004.07.020

Bănărescu, P. (1964). Fauna Republicii Socialiste Romania. Pisces-Osteichthyes. Editura Academiei R.S.R., București XIII, 1: $958 \mathrm{p}$.

Benlier, E., Alicioglu, B., Kir, K., Sarikaya, A. (2010). Using liposuction for late complication of Trachinus draco envenomation. Aesthetic Plastic Surgery, 34(2), 179.

https://doi.org/10.1007/s00266-009-9406-0

Berger, L., Caumes, E. (2004, April). Accidents cutanés provoqués par la faune et la flore sous-marines. In Annales de Dermatologie et de Vénéréologie, 131(4), 397-404 https://doi.org/10.1016/S0151-9638(04)93626-5

Borges, L. (2001). A new maximum length for the snipefish Macrohamphosus scolopax. Cybium, 25, 191-192.

Bourée, P., Lançon, A. (2002). Les animaux aquatiques dangereux. Revue Francaise des Laboratoires, 2002(342), 61-64. https://doi.org/10.1016/S0338-9898(02)80063-4

Buz, K., Başusta, N. (2015). Age and growth of the greater weever, Trachinus draco (Linnaeus, 1758) inhabiting Iskenderun Bay, North-Eastern Mediterranean Sea. Cahiers de Biologie Marine, 56, 289-295. 
Carpenter, K.E., Smith-Vaniz, W.F., de Bruyne, G., de Morais, L. (2015). Trachinus draco. The IUCN Red List of Threatened Species, 2015, e.T198719A42691954.

https://doi.org/10.2305/IUCN.UK.2015-

4.RLTS.T198719A42691954.en

Chahl, L.A., Kirk, E.J. (1975). Toxins which produce pain. Pain, 1(1), 3-49.

https://doi.org/10.1016/0304-3959(75)90003-2

Chhatwal, I., Dreyer, F. (1992). Biological properties of a crude venom extract from the greater weever fish Trachinus draco. Toxicon, 30(1), 77-85.

https://doi.org/10.1016/0041-0101(92)90503-W

Church, J.E., Hodgson, W.C. (2002). The pharmacological activity of fish venoms. Toxicon, 40(8), 1083-1093. https://doi.org/10.1016/S0041-0101(02)00126-5

Coull, K.A., Jermyn, A.S., Newton, A.W., Henderson, G.I., Hall, W.B. (1989). Length/weight relationships for 88 species of fish encountered in the North Atlantic. Scottish Fisheries Research Reports, 43, 1-80.

Crec'hriou, R., Neveu, R., Lenfant, P. (2013). Lengthweight relationship of main commercial fishes from the French Catalan coast. Journal of Applied Ichthyology, 29, 1191-1192.

https://doi.org/10.1111/jai.12320

Čustović, S., Vrgoč, N., Isajlović, I., Šifner, S.K., Krželj, M., Ferri, J. (2014). Growth dynamic of the greater weever (Trachinus draco Linnaeus 1758) in the Northern and Central Adriatic. 49. hrvatski i 9. međunarodni simpozij agronoma, 16. do 21. veljače 2014, Dubrovnik, Hrvatska. Zbornik Radova, 448-452.

Djabali, F., Brahmi, B. Mammasse, M. (1993). Poissons des côtes algériennes. Pelagos, N. spec., 1-215.

Dorel, D. (1986). Poissons de l'Atlantique Nord-Est: Relations Taille-Poids. DRV-86-001/RH/NANTES. Ifremer Report. DRV. https://archimer.ifremer.fr/doc/00000/1289/ (accessed: $15 / 05 / 2020)$.
Dulčić, J., Kraljević, M. (1996). Weight-length relationships for 40 fish species in the eastern Adriatic (Croatian waters). Fisheries Research, 28(3), 243-251.

https://doi.org/10.1016/0165-7836(96)00513-9

Dulčić, J., Soldo, A. (2005). A new maximum length for the grey triggerfish, Balistes capriscus Gmelin, 1789 (Pisces: Balistidae) from the Adriatic Sea. Institute of Oceanography and Fisheries-Split Croatia, 88, 1-7.

Erzini, K., Stergiou, K.I., Bentes, L., Economides, P.S., Gonçalves, J.M.S., Lino, P.G., Moutopoulos, D.K., Petrakis G., Ribeiro, J., Voulgaridou, P. (1999). Comparative fixed gear selectivity studies in Portugal and Greece. Final Report to the European Union (EU No 96/065). University of Algarve and Aristotle University of Thessaloniki.

Evans, H.M. (1907). Observations on the poisoned spines of the weever fish (Trachinus draco). British Medical Journal, 1(2402), 73.

https://doi.org/10.1136/bmj.1.2402.73

Fischer, W., Schneider, M., Bauchot, M.L. (1987). Fiches FAO d'identification des espèces pour les besoins de la pêche: Méditerranée et mer noire zone de pêche 37: vol. 2 vertébrés: ((FAO species identification sheets for fishery purposes. Mediterranean and Black Sea (Fishing Area 37). vol. 2 vertebrates.).

Frimodt, C. (1995). Multilingual illustrated guide to the world's commercial coldwater fish. Fishing News Books, Osney Mead, Oxford, England. 215 p.

Froese, R., Binohlan, C. (2000). Empirical relationships to estimate asymptotic length, length at first maturity, and length at maximum yield per recruit in fishes, with a simple method to evaluate length frequency data. Journal of Fish Biology, 56(4), 758-773.

https://doi.org/10.1111/j.1095-8649.2000.tb00870.x

Froese, R., Pauly, D. (2020). FishBase. World Wide Web electronic publication. www.fishbase.org, version (10/2017) (accessed: 27 May 2020).

Garmón, A.C. (2005). Biología, dinámica poblacional y tasas de mortalidad y explotación pesquera de Trachinus 
draco en las Islas Baleares (Mediterráneo Occidental) (Master dissertation).

Giacalone, V.M., Anna, G.D., Badalamenti, F., Pipitone, C. (2010). Weight-length relationships and condition factor trends for thirty-eight fish species in trawled and untrawled areas off the coast of Northern Sicily (Central Mediterranean Sea). Journal of Applied Ichthyology, 26, 954-957. https://doi.org/10.1111/j.1439-0426.2010.01491.x

Gonçalves, J.M.S., Bentes, L., Lino, P.G., Ribeiro, J., Canário, A.V.M., Erzini, K. (1997). Weight-length relationships for selected fish species of the small-scale demersal fisheries of the south and South-West coast of Portugal. Fisheries Research, 30(3), 253-256.

https://doi.org/10.1016/S0165-7836(96)00569-3

Gökçe, G., Çekiç, M., Filiz, H. (2010). Length-weight relationships of marine fishes off Yumurtal1k coast (Iskenderun Bay), Turkey. Turkish Journal of Zoology. 34, 101-104.

Halstead, B.W., Vinci, J.M. (1987). Venomous fish stings (Ichthyoacanthotoxicoses). Clinics in Dermatology, 5(3), 2935 .

https://doi.org/10.1016/S0738-081X(87)80005-6

Hamed, O., Chakroun-Marzouk, N. (2016). First investigation on the reproductive traits of Trachinus radiatus $\mathrm{Cu}-$ vier, 1829. Rapports de la Commission Internationale pour l'Exploration Scientifique de la Mer Méditerranée, 41, 457.

Helfman, G.S, Collatte, B.B, Facey, D.E., Bowen, B.W. (2009). The diversity of fishes: biology, evolution, and ecology, $2^{\text {nd }}$ edn, Wiley-Blackwell, UK, 720 pp.

IGFA 2001. Database of IGFA angling records until 2001. IGFA, Fort Lauderdale, USA.

Ilkyaz, A.T., Metin, G., Soykan, O., Kinacigil, H.T. (2008). Weight-Length relationships of 62 fish species from the Central Aegean Sea, Turkey. Journal of Applied Ichthyology, 24, 699-702.

https://doi.org/10.1111/j.1439-0426.2008.01167.x
Ismen, A., Ozen, O., Altinagac, U., Ozekinc, U., Ayaz, A. (2007). Weight-Length relationships of 63 fish species in Saros Bay, Turkey. Journal of Applied Ichthyology, 23, 707708.

https://doi.org/10.1111/j.1439-0426.2007.00872.x

Karachle, P.K., Stergiou, K.I. (2008). Length-Length and weight-length relationships of several fish species from the North Aegean Sea (Greece). Journal of Biological ResearchThessaloniki, 10, 149-157.

Karakulak, F.S., Erk, H., Bilgin, B. (2006). Length-weight relationships for 47 coastal fish species from the northern Aegean Sea, Turkey. Journal of Applied Ichthyology, 22(4), 274-278.

https://doi.org/10.1111/j.1439-0426.2006.00736.x

Kayiş, Ş., Akif, E.R. (2016). First record of Nerocila bivittata (Cymothidae, Isopoda) on Greater Weever (Trachinus draco) in the Worldwide. Aquaculture Studies, 16(4), 335339.

https://doi.org/10.17693/yunusae.v16i26717.281033

Kinacigil, H.T., İkyaz, A.T., Metin, G., Ulaş, A., Soykan, O., Akyol, O., Gurbet, R. (2008). Determining the first reproduction length, age and growth parameters of Aegean Sea demersal fish for the regulation of fisheries management. TÜBİTAK-ÇAYDAG, 327p. (in Turkish).

Legendre, M., Albaret, J.J. (1991). Maximum observed length as an indicator of growth rate in tropical fishes. Aquaculture, 94, 327-341.

https://doi.org/10.1016/0044-8486(91)90177-9

Linnaeus, C. (1758). Systema naturae per regna tria naturae, secundum classes, ordinus, genera, species, cum characteribus, differentiis, synonymis, locis. Tomus I. Editio decima, reformata. Impensis Direct. Laurentii Salvii, Holmiae. 824 p. https://doi.org/10.5962/bhl.title.542

Lopaciński, B., Bak, M., Fiszer, M., Czerniak, P., Krakowiak, A. (2009). Poisoning with weever fish venom: a case report. Przeglad Lekarski, 66(8), 464-465.

Loukas, V., Dimizas, C., Sinanoglou, V.J., MiniadisMeimaroglou, S. (2010). EPA, DHA, cholesterol and phospholipid content in Pagrus pagrus (cultured and wild), 
Trachinus draco and Trigla lyra from Mediterranean Sea. Chemistry and Physics of Lipids, 163(3), 292-299.

https://doi.org/10.1016/j.chemphyslip.2010.01.004

Mata, A.J., Morales, J., Marquez, L. (2008). WeightLength relationships for 26 demersal fish species of the Spanish South-Atlantic coastal waters. Journal of Applied Ichthyology, 24, 330-333.

https://doi.org/10.1111/j.1439-0426.2008.01058.x

Mendes, B., Fonseca, P., Campos, A. (2004). WeightLength relationships for 46 fish species of the Portuguese west coast. Journal of Applied Ichthyology, 20(5), 355-361. https://doi.org/10.1111/j.1439-0426.2004.00559.x

Mendes, B., Fonseca, P., Campos, A. (2006). Relationships between opercula girth, maximum girth and total length of fish species caught in gillnet and trammel net selectivity surveys off the Portuguese coast. Journal of Applied Ichthyology, 22(3), 209-213.

https://doi.org/10.1111/j.1439-0426.2006.00734.x

Merella, P., Quetglas, A., Alemany, F., Carbonell, A. (1997). Weight-length relationships of fishes and cephalopods from the Balearic Islands (western Mediterranean). Naga ICLARM Quarterly, 20(3-4), 66-68.

Morey, G., Moranta, J., Massuti E., Grau A., Linde M., Riera F., Morales-Nin B. (2003). Weight-Length relationships of littoral to lower slope fishes from the Western Mediterranean. Fisheries Research, 62, 89-96.

https://doi.org/10.1016/S0165-7836(02)00250-3

Moutopoulos, D.K., Stergiou, K.I. (2002). Length-Weight and length-length relationships of fish species from the Aegean Sea (Greece). Journal of Applied Ichthyology, 18(3), 200-203.

https://doi.org/10.1046/j.1439-0426.2002.00281.x

Moutopoulos, D.K., Ramfos, A., Mouka, A., Katselis, G. (2013). Length-Weight relations of 34 fish species caught by small-scale fishery in Korinthiakos Gulf (Central Greece). Acta Ichthyologica et Piscatoria. 43(1), 57-64.

https://doi.org/10.3750/AIP2013.43.1.08
Muus, B.J., Nielsen, J.G. (1999). Sea fish. Scandinavian Fishing Year Book, Hedehusene, Denmark. 340 p. ISBN: 8790787-00-5

Otel, V. (2007). The Atlas of the fish species of the Danube Delta Biosphere Reserve. Edit. Centrul de Informare Tehnologica Delta Dunarii: Tulcea, Romania.

Ozaydin, O., Uckun, D., Akalin, S., Leblebici, S., Tosunoglu, Z. (2007). Length-Weight relationships of fishes captured from Izmir Bay, Central Aegean Sea. Journal of Applied Ichthyology, 23, 695-696.

https://doi.org/10.1111/j.1439-0426.2007.00853.x

Öztekin, A., Özekinci, U., Daban, I.B. (2016). LengthWeight relationships of 26 fish species caught by longline from the Gallipoli peninsula, Turkey (northern Aegean Sea). Cahiers de Biologie Marine, 57, 335-342.

Özdemir, S., Özsandıkçı, U., Büyükdeveci, F., Erdem, Y., Özdemir, Z.B. (2017). Some Biological Characteristics and Length-Weight Relationship of Dangerous Venomous Fishes from Black Sea Coasts. ISEEP-2017 VIII. Internatıonal Symposium on Ecology and Environmental Problems. Çanakkele, Turkey: 402.

Pauly, D. (1980). On the interrelationships between natural mortality,growth parameters, and mean environmental temperature in 175 fish stocks. Journal du Conseil International pour l'Exploration de la Mer, 39, 175-192.

https://doi.org/10.1093/icesjms/39.2.175

Perrière, C., Michel, C. (1986). Les glandes operculaires de la petite vive, Trachinus vipera C.V.(Téléosteens, Trachinoidea, Trachinidae). Cahiers de Biologie Marine, 27, 469-490.

Portillo Strempel, A., Baro Domínguez, J., Mancera, Romero, J.M., Herrera Ceballos, E., Ceballos, R. (2008). Distribución espacial de Trachinus draco (Linnaeus, 1758), (Pesciforme, Trachinidae) en el norte del Mar de Alborán (España). Zoologica Baetica, 19, 3-14.

Portillo Strempel, A., Herrera Ceballos, E. (2014). Histology of the venom gland of Trachinus draco (A. ctinopterygii, T. rachinidae). Acta Zoologica, 95(2), 125-132.

https://doi.org/10.1111/azo.12004 
Quigley, D.T.G., Flannery, K. (1994). Fish Notes. The Irish Naturalists' Journal, 24(10), 408-412.

Quigley, D.T.G., Flannery, K., O'Shea, J. (1990). The Greater Weever Trachinus draco (L.) in Irish waters: First Record from Co. Mayo and a Review of Irish Records. The Irish Naturalists' Journal, 23(5/6), 208-210.

Rimel, B., Mourad, C., Koched, W. (2015). Length-Weight relationships of 15 ground fish species caught in Tunisian deep water (SW Mediterranean Sea). International Journal of Recent Scientific Research, 6(9), 6386-6388.

Roșca, I., Arteni, O.M., Ion, I. (2010). Recent data on some benthic fish populations of the Black Sea coast (Agigea Eforie Nord Area). Analele Științifice ale Universității, Al. I. Cuza” Iași, s. Biologie animală, Tom LVI, 2010.

Russell, F.E., Emery, J.A. (1960). Venom of the Weevers Trachinus draco and Trachinus vipera. Annals of the New York Academy of Sciences, 90(3), 805-819.

https://doi.org/10.1111/j.1749-6632.1960.tb26424.x

Sangun, L., Akamca, E., Akar, M. (2007). Weight-Length relationships for 39 fish species from the North-Eastern Mediterranean coast of Turkey. Turkish Journal of Fisheries and Aquatic Sciences, 7(1), 37-40.

Šantić, M., Pallaoro, A., Rađa, B., Jardas, I. (2016). Diet composition of greater weever, Trachinus draco (Linnaeus, 1758) captured in the eastern-central A driatic Sea in relation to fish size, season and sampling area. Journal of Applied Ichthyology, 32(4), 675-681.

https://doi.org/10.1111/jai.13081

Santos, M.N., Gaspar, M.B., Vasconcelos, P., Monteiro, C.C. (2002). Weight-Length relationships for 50 selected fish species of the Algarve coast (southern Portugal). Fisheries Research, 59, 289-295.

https://doi.org/10.1016/S0165-7836(01)00401-5
Torres, M.A., Ramos F., Sobrino I. (2012). Weight- Length relationships of 76 fish species from the Gulf of Cadiz (SW Spain). Fisheries Research, 127, 171-175.

https://doi.org/10.1016/j.fishres.2012.02.001

Tortonese, E. (1986). Trachinidae. p. 951-954. In J.C. Hureau and Th. Monod (eds.) Checklist of the fishes of the North-Eastern Atlantic and of the Mediterranean (CLOFNAM). UNESCO, Paris. Vol. 2. ISBN: 92-3-0011002

Verdiglione, R., Mammola, C.L., Gargano, M., Montesi, F. (2003). Ultrastructure of Venom Glands in Trachinus draco (Osteichthyes, Trachinidae). Italian Journal of Anatomy and Embryology (Archivio Italiano di Anatomia ed Embriologia), 108(3), 182.

Welcomme, R.L. (1999). A review of a model for qualitative evaluation of exploitation levels in multi-species fisheries. Fisheries Management and Ecology, 6, 1-19. https://doi.org/10.1046/j.1365-2400.1999.00137.x

Went, A.E.J. (1973). Some interesting fishes taken from Irish Waters in 1972. The Irish Naturalist' Journal, 17(11), 375-378.

Wilhelms, I. (2013). Atlas of length-weight relationship of 93 fish and crustacée species from the North Sea and the North-East Atlantic ( $\mathrm{N}^{\mathrm{o}}$. 12). Johann Heinrich von Thünen Institute, Federal Research Institute for Rural Areas, Forestry and Fisheries. ISBN: 978-94-009-0829-1

https://doi.org/10.1007/978-94-009-0829-1_1

Wootton, R.J. (1990). Ecology of teleost fishes. Fish and Fisheries Series 1. Chapman \& Hall, London, 404. ISBN: 978-94-009-0829-1

Wootton, R. J. (1999). Ecology of teleost fishes, 2nd edn.Fish and Fisheries Series No. 24. New York: SpringerVerlag. ISBN: 978-94-010-6859-8 